\title{
COM \\ Beyond the Base-ics: approaches to driving connection through genetics in museums
}

Abstract

\section{Keywords}

DOI

Introduction

\section{Abigail A. Howell, Keighley N. Reisenauer, Michelle M. Valkanas and Katherine E. Carter}

Genetics literacy is crucial for making informed decisions. However, perceived complexity, educational gaps, and misleading media narratives make reaching diverse populations difficult. Interventions to improve genetics literacy beyond K-12 classrooms should center on building science trust and self-efficacy. We used a mixed methods approach to survey 12 museums with genetics content and found 3 framing devices, "Genetics is Fun," "Genetics is Relevant," and "Genetics is Discovery." While each framing strategy leads to high engagement with genetics topics, these approaches differed in ways that affect ability to learn and how genetics is perceived. Exhibit creators should consider design ramifications when creating a genetics exhibit that builds genetic literacy.

Informal learning; Public engagement with science and technology; Science centres and museums

https://doi.org/10.22323/2.21010202

Submitted: 5th October 2021

Accepted: 3rd December 2021

Published: 24th January 2022

Genetics literacy, the ability for individuals to understand genetic information and how it influences your everyday life, is becoming crucial for making informed personal decisions. With rapid advances in genetic technology, a foundational understanding of genetics is now important for meaningful engagement with questions surrounding health, privacy, and policy. Improving genetic literacy correlates with increases in trust in science and greater satisfaction with health decisions and decreases in the prevalence of naturalistic fallacies about race [Donovan, Semmens et al., 2019; Donovan, Weindling et al., 2020]. Despite prevailing positive attitudes toward the use of genetics information, a high percentage of the general population lacks basic knowledge necessary to interpret disease risk and genetic susceptibility [Abrams et al., 2016; Scheuner, Sieverding and Shekelle, 2008; Smerecnik et al., 2008], to understand human evolutionary ancestry [Bobkowski, Watson and Aromona, 2020; Roth et al., 2020], and to evaluate whether participation in genetic testing is an appropriate choice [Chen and Goodson, 2007; Ciske et al., 2001; Sauven, 2004]. 
Interventions to improve genetics literacy, particularly to those beyond a $\mathrm{K}-12$ classroom, requires an approach that builds science trust and self-efficacy. Museums and other informal learning environments, such as libraries and nature centers, serve over 100 million visitors across the United States each year and are among the most trusted venues for science information [MacFadden, 2008]. In addition, museums and other informal learning centers can foster discussion across multiple age cohorts [Diamond, 1986; Duensing, 2006; Ellenbogen, 2003;

Zimmerman, Reeve and Bell, 2009; Falk, Dierking et al., 2016] and provide a semi-structured, free-choice learning environment that allows the multi-directional bridging of knowledge between school and home [Miller and Barrington, 1981a; Miller and Barrington, 1981b]. While museums have a historical role in displaying, cataloging, and communicating knowledge, recent analyses have focused on these institutions' capacity for recontextualization and co-creation of knowledge [Antón, Camarero and Garrido, 2017; Falk and Storksdieck, 2005; Henning, 2006; Rock, McGuire and Rogers, 2018; Taffe and Kelly, 2020].

Evidence suggests that increased exposure to genetic information in and of itself is not effective in driving visitors to informal learning environments to seek more information about genetics and to see themselves as part of the scientific process [Hinojosa, 2020; Hinojosa, Swanson and Polman, 2018; Holmes, 2011; Kelly, 2007; Wilde and Urhahne, 2008; Zimmerman, Reeve and Bell, 2009]. Instead, the design choices used to help visitors engage with genetics and evolution information dramatically impact visitor understanding, interest, and feelings of inclusion [Dunbar and Klahr, 2013; Andrew Elby, Scherr and Redish, 2004]. Many of these choices concern the subject and approach of the exhibit itself. For example, exhibits focusing on genetic mechanisms such as transcription and translation are less well understood and often less appreciated than exhibits focusing on observable phenomena such as stratigraphy [Evans et al., 2010; MacFadden, 2008; Tison Povis, 2017]. In addition, experiences that tell personal stories [National Research Council, 2000] take advantage of local connections [Bonham et al., 2009; University of Michigan School of Public Health, 2007], and use unconventional learning approaches, such as video resources or gamification [Pearson and Liu-Thompkins, 2012; Falk, Dierking et al., 2016; Sabatello et al., 2019], are more effective at driving understanding and establishing positive affinity with science.

Just as important as design and content choices to visitor interaction and understanding are the decisions about framing genetic information. While there have been no studies of the impacts of framing in genetics in museums, there have been a wealth of studies on the impacts of framing genetics within the broader conversation. Science communication around genetics frequently focuses on the novelty of new technologies, framing these developments as either making unprecedented breakthroughs or going too far towards "playing God" [Hellsten and Nerlich, 2008]. Media coverage of these discoveries also perpetuate these narrow framing choices, particularly the "nature versus nurture debate," the metaphor of genetics as "deciphering life's code," and of genes coding directly for individual traits [Gallop et al., 2017; Kampourakis, 2016; Pramling and Säljö, 2007; Stern and Kampourakis, 2017; Zolyan, 2020]. De-emphasizing the "medical model" of genetics communication, focusing on polygenic rather than monogenic traits, and including developmental and phenotypic plasticity early in the curriculum all serve as effective means of avoiding these problematic metaphors and building inclusive frames of genetic knowledge in the formal education space [Donovan, 
2016; Donovan, Semmens et al., 2019; Hales, 2020; Jamieson and Radick, 2017]. While the implications of framing science in museums have been studied in exhibits on phylogeny [Stephens, 2012], climate change [Kirk, 2017], and anatomy [Pedretti, Navas-Iannini and Nazir, 2018], there has been little work done on the impact of the framing of genetics content in museums, despite the growing realization of the importance of subtext and context in driving visitor understanding. By performing interviews with museum education professionals, we aim to analyze the impact of design decisions in genetics exhibits and draw conclusions about the role design plays in fostering genetics literacy and understanding. The goal of this research is to analyze emergent themes for effective frames for genetic literacy and how they uniquely foster learning in genetics among adults and families.

Methods

Two authors (AAH and KNR) conducted semi structured interviews with museum education professionals at twelve science centers and museums to explore the learning goals and frames of genetics exhibits. The museums were:

- Arizona Science Center

- Burke Museum

- Cincinnati Museum

- Denver Museum of Nature \& Science

- Florida Museum of Natural History

- Institute of Genomic Biology (IGB)

- Nebraska State Museum

- Oregon Museum of Science and Industry

- Perot Museum

- Science North (in Sudbury, Ontario)

- St. Louis Science Center

- Utah Natural History Museum

Museums were selected through two individual search methods: 1) AAH used the Google search engine to search for the terms "[STATE]" or "[PROVINCE]" for each of the fifty U.S. states and Canada, "genetics", and "exhibit"; 2) MMV used the online encyclopedia Wikipedia and searched the phrase "List of museums in [STATE] or [PROVINCE]" for each of the fifty U.S. states and Canada. All museums meeting initial inclusion criteria were then analyzed further by visiting their individual websites and reviewing their current exhibits. Additionally, an advanced Google search (https:/ / www.google.com/advanced_search) was performed using genetic terminology restricted to the museum website. This was completed by inserting all genetic terminologies in the "Find pages with any of these" section and inserting museum website homepage into the "Narrow your search by site or domain" section. This method was used to capture all potential museum exhibitions and not exclude small museums. Results between the two 
techniques were broadly similar, with about $82 \%$ correspondence between searches. Museums that had a genetic exhibit currently on display that was created by the museum were included for further study. Travelling exhibits were excluded unless the exhibit was currently being displayed by the museum responsible for its development. Search results that matched exhibit design were recorded, while online supplemental material for classrooms and at home activities were not included.

All museums meeting these criteria were contacted using the museum's general contact information located on their respective websites. Overall, 77 museums were contacted. Of the museums that responded, interviewers were put in contact with individuals that were directly involved in the development of a genetics exhibit created at each museum. Interviewees had a broad range of official job descriptions within the museums including; Chief of Science \& Curiosity, Director of Interpretation \& Visitor Experience, Curator of Zoology, Genetics Lab Research Manager, Director of Exhibits \& Public Programs, Outreach Activities Manager, Professor and Curator, Featured Hall Manager, Vice President of Exhibits, staff scientist, and Manager of STEM Events. Interviewee education levels ranged from Bachelor's (4) to Master's (6) to PhD (2).

Twelve professionals from museums offered insights into the strategic decisions shaping current and recent genetics content in the United States (and Canada, which is culturally similar). Museums were in the Midwest (Illinois, Missouri, Nebraska, Ohio), the South (Florida, Texas), the West (Colorado, Oregon, Utah, Washington), and Canada (Ontario). Interviewers AAH and KNR spoke to curators and exhibit designers, scientists, and outreach specialists. Five of the twelve museums $(41.7 \%)$ were affiliated with universities.

We analyzed the interview data using a mixed-methods approach. The semistructured interview format allowed the interviewers to address both predetermined and emergent topics [Lofland and Lofland, 1995]. Audio recordings of interviews were transcribed verbatim using the software Otter.ai (http:/ / otter.ai). Researchers used a structural codebook framework [Ryan and Bernard, 2003] to iteratively analyze the transcripts for emergent themes related to exhibit hall contents, exhibit topics, interpretation, design approach, learning goal topics and development, hooks, and evaluation. The multistage coding process began with both researchers individually coding two interview transcripts from different timepoints, with an interobserver error of around $20 \%$. In the second iteration of the codebook. researchers removed "exhibit hall contents" and added an additional criterion of "motivation" (i.e., the primary reason the museum/institution created a genetics exhibit). The second iteration also included definitions and text examples from interviews to provide further guidance and specificity. The revised codebook was used to code two different transcripts, with an interobserver error of $10 \%$. This final codebook was then used to code the remaining ten transcripts. Using the interviews and codes, qualitative analysis was done to understand motivations behind design choices and construction of emergent themes. In addition, quantitative analysis was conducted with the software package factoextra. The codes were analyzed for emergent themes using k-means clustering analysis, with a random partition initialization metric and iterated over (1 to $\mathrm{n}-1)$ means using the kmeans function in $\mathrm{R}$. 
We conducted semi-structured interviews structured into "back-end" and "front-end" questions, focusing on the behind-the-scenes decisions that fueled the resulting exhibit product. During the interviews, many of the conversations were filled with energy and passion. The predominant factor in driving the creation of the genetics exhibits were a recognition of the importance of genetics and a desire to bring a genetics exhibit to life within the museum (Figure 1a). Research, either showing the museum as a scientific body or fostering partnerships with universities who would conduct on-site research, was another major theme that drove the development of genetics exhibits. Overall, most of the interviewees described a workflow centered on what the exhibit's curatorial and design teams chose to talk about and how to talk about the desired topic, with the desired outcome or learning objectives being secondary (Figure 1b). All conversations mentioned a desire for visitors to learn about the provided content, but not all had a clear vision of how to achieve that goal. Only three museums (Nebraska, IGB, Denver) reportedly centered museumgoer learning in their approach to exhibit implementation. All three that were scored as having learning goal-centered approaches also incorporated evaluation methods such as soliciting feedback from visitors (interviews, feedback slips, and polling) and tracking visitor/participant demographics. Many museums also spoke about design choices being influenced by the need to develop travelling exhibitions, satisfy the needs of external stakeholders, or satisfy previous grant commitments (captured under external needs).

When discussing how museum curators decided which topics to include in the exhibit, almost every museum (10 of 12) prioritized concepts deemed relevant to the visitors' lives such as health and genetic testing, trait inheritance and heritage, or genetics-based jobs (Figure 1c). Many of the museums expressed a deeper desire for visitors to understand that genetics is not a new concept and that it is not removed from their daily life. Building on this, two thirds of museums focused on genetics research or recent breakthroughs. However, there was not a correlation between the museums that were likely to have direct access to research via a university affiliation and a conversation about research in genetics. Not all university museums chose to focus on the importance of genetics research, and some museums without academic affiliations focused on the importance of genetics research, nevertheless. The choices about how to "hook" the reader into initial investigation varied as well (Figure 1d). Eight of the twelve museums emphasized that they had volunteers and staff available to help interpret and engage with the exhibit, either via researchers with labs integrated into the exhibit and/or via ambassadors or volunteers. Often, if museums implemented assisted interpretation, they also expressed learning goals stemming from conversations with local scientists ( 5 of 8 ). These goals did not follow a pattern, however. Outside of making genetics relevant to visitors, the most common goals for the exhibit were to produce an understanding about genetics facts (for example, the function of ribosomes, 5 of 12), or learning goals about scientists or research (for example, scientists are diverse, 5 of 12). Evaluation differed significantly among the museums, with many museums preferring more passive methods of feedback (e.g., demographic data collection, passive feedback, or the collection of visitor data through exhibit components). When active evaluation was conducted, it often focused on satisfaction surveys (4 of 12) and participant observation of conversations (2 of 12). 

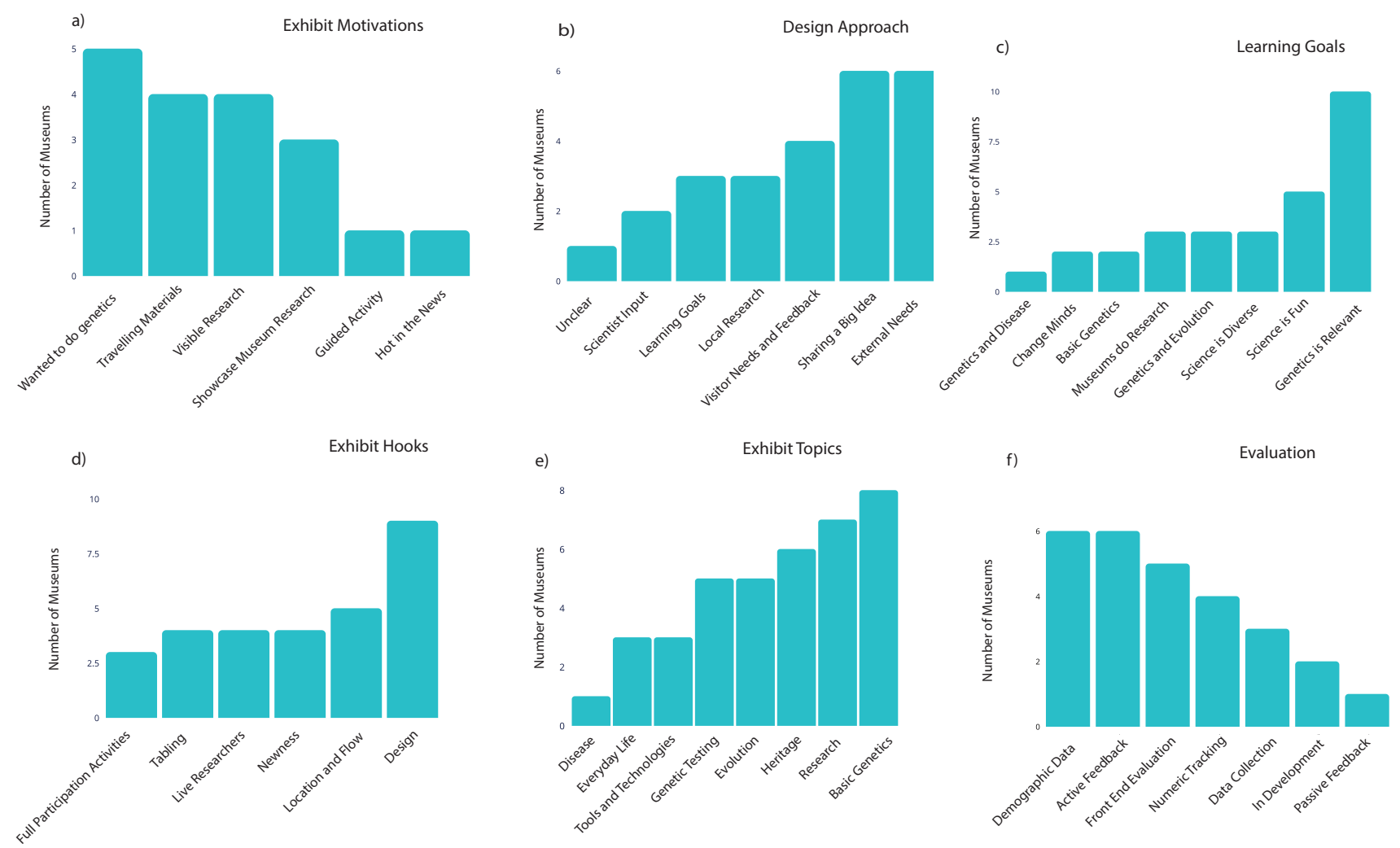

Figure 1. Summary of approaches for building genetics exhibits taken by museums interviewed for this study. A museum may be represented by multiple categories or may not be represented in a particular category. a) Shows the various motivations behind building the exhibit, while b) highlights the different design approaches taken to realizing it. c) refers to stated learning goals of an exhibit that were developed before the opening of the exhibit. d-e) reflect the hooks for audience engagement used as well as the topics eventually covered by the museum. Both of these can be different that the initial plans. Finally, f) refers to the different evaluation techniques used by the museums.

\section{Approaches to Genetics}

We applied an appropriate statistical method (k-means clustering) to the data from the coded interviews to separate the exhibits into groups based on their approach to presenting genetics. The results suggest that there are three major approaches to genetic museum exhibitions, which may be described briefly as "Genetics is Fun," "Genetics is Relevant," and "Genetics is Discovery."

Genetics is Fun: St. Louis Science Center (MO), Perot Museum of Nature and Science (TX), Science North (Ontario)

The category "Genetics is Fun" includes museums that expressed a desire for "visitors to have fun interacting with the exhibit" or included interactive 
elements/gamification as a key part of their exhibit design. The following are representative quotations from staff at museums in this category:

St. Louis Science Center: "Everybody wants to sort of like, touch, touch, touch and fun, find fun, and maybe I'll learn something along the way."

Perot Museum of Nature (Perot): "Fun becomes a big portion of what we want to make sure people are saying, so when we get word bubbles about your experience in the museum, usually fun ranks up there pretty high."

A core component of this approach is an emphasis on front-end evaluation, visitor feedback, and timing and tracking data. Understanding the experiential dimensions of the visit - how it makes visitors feel and how it might enrich their lives - is important to understanding the aspects of the exhibit the visitors look forward to and communicate with others [Ritchie and Hudson, 2009; Schmitt-Scheersoi, Vogt and Naumann, 2002] . By better understanding visitor perspectives, museums can connect with visitors to encourage personal meaning-making and satisfying experiences.

Perot: We tend to focus less on our evaluation in terms of what did you learn in the hall, but more about what were you interested in and what things did you find interest in the hall.

The qualitative analysis also shows that these types of museums focus primarily on inheritance and genetic tools and technology in their exhibit topics and that they are also very volunteer-based in their exhibit interpretation. Science North distinctively utilizes its interactive elements and volunteers to teach inheritance through its object theater "Club Genome."

Science North: So it [object theater] is a theater that presents a show, and has physical objects that kind of explain the story like throughout the show, so as a visitor they're engaging with it and watching it... Or for us at our science center, we call our staff blue coats, because we literally were like blue lab coats. So you know, visitors get to interact with blue coats and ask different questions.

Science North: [In] club genome. And we had, we had kind of like a, it was sort of like the little like disco inside. So the tables all lit up. And there were like flashing lights and colored lights...

\section{Genetics is Relevant: University of Nebraska State Museum, Carl R. Woese Institute for Genomic Biology (IL), Arizona Science Center, Natural History Museum of Utah, Oregon Museum of Science and Industry}

The central theme of the second category of museums was "Genetics Is Relevant," highlighting a variety of researchers and genetics topics in what were usually a part of a series of travelling exhibits. 
Nebraska: But how do you make this story? You know, meaningful?... but you know, for the people who serve are in denial and think, oh, museums change people, and all my exhibits are so important. You know, that seems like oh, that's not very much, you know, but maybe it's a lot.

Nebraska: Yeah. And maybe, that, you know, I've always believed that what museums do is part of a bigger project

IGB: translate genomics research and DNA research for the public to make it so that they feel comfortable making decisions about genomics in their everyday life

Health testing and DNA basics were two topics that were uniquely covered in this category. Studies show that educational interventions have been successful with respect to changing perceptions about direct-to-consumer genetics tests, indicating that museum exhibits focused on health testing are an effective strategy for increasing genetic literacy [Pearson and Liu-Thompkins, 2012]. The emphasis on DNA basics in these exhibits possibly stems from the adherence to state standards on genetics content reported by museum curators in interviews, which focuses primarily on conceptual knowledge components of genetic literacy rather than sociocultural or epistemic knowledge components.

Utah and OMSI stand out as a subcategory within this group. While they also emphasize research, travelling components, and building awareness in their design choices, their exhibit topics focus less on a variety of genetics concepts than on an overarching theme of a single topic. Museum staff interviewed described this as the "big idea" of the exhibit.

OMSI: And so we've decided to make a connection between science and this like cultural history. Genghis Khan, Mongol Empire thing. We're connecting them with genetics.

\section{Genetics is Discovery: Florida Museum of Natural History, Burke Museum of Natural History and Culture (WA), Denver Museum of Nature \& Science (CO), Cincinnati Museum Center $(\mathrm{OH})$}

The exhibits at museums in this category center on a "glassbox"-style genetics lab, where visitors can peer in and watch scientists at work. The primary goal of these types of exhibits is to showcase that museums actively conduct research using their collections and aren't simply a static "cabinet of curiosities". Visitor misconceptions about the purpose of museum collections threaten funding, which has already been declining since the economic crisis of 2008 [Kemp, 2015].

Florida: For us, it also helps because we're a collections based museum. And we have 40 million objects in our collections. So people often say why do you need so many things? You know, why isn't one butterfly of a certain species enough? Why do you have to kill multiple butterflies of the same species and so the genetics lab gave us an opportunity to talk about, you know, how science is conducted? 
Genetics research using museum collections is critical to advancing our understanding of biodiversity and how evolution shapes our world. Collections research also provides invaluable insights into how populations are changing, and even being threatened, in the face of climate change [Wandeler, Hoeck and Keller, 2007]. By showcasing visible research in the exhibit, these museums can combat visitor misconceptions about the role of collections in museums. Observing live researchers also increases visitor understanding of the practices in which genetic technology is applied and the process of science, which are important concepts in genetic literacy.

Some museums have taken this practice a step further by inviting museum visitors to participate in ongoing research. In the Denver Museum of Nature \& Science's "Genetics of Taste Lab," participants contribute phenotypic and genetic data to the lab's taste and genetics research studies. Through participation in this study, the visitors become familiar with the scientific process and can understand how the study relates to their own lives. Evaluation data from this study shows that guests both enjoy and value participating in authentic genetics research [Nuessle, McNamara and Garneau, 2020].

Denver: the goal is when they look in, and they see us working on actual science, that they see us wearing similar things, and they make the connection that they're scientists as well, and that there's a scientist to everybody.

Though each exhibit cluster demonstrated a different approach to building genetics literacy, several museums did fall into one or more clusters. For example, a museum that framed genetics as something that is both doable and exciting may have fallen between the "Genetics is Fun" and the "Genetics is Relevant" categories. Other museums used live researchers but had them do more traditional museum interpretations, placing them within the "Genetics is Fun" and "Genetics is Discovery" category. Other museums had such large genetics exhibits that they touched on all three approaches during the interviews. While there is certainly overlap between approaches, we believe that analyzing these three categories will allow drawing distinctions between emergent metaphors, understanding of audience, and design choice.

Within the existing genetics exhibits, approaches to displaying and framing the content differed in ways that affect ability to learn and how genetics is perceived [Dunbar and Klahr, 2013; Andrew Elby, Scherr and Redish, 2004; Nisbet and Mooney, 2007]. Discussions of how genetics has been framed have centered mainly on its novelty or its consequences, ignoring the ways in which genetics has been framed as a discipline or as a scientific endeavor. Here we discuss how the design choices, messaging strategies, and learning goals of the emergent categories of framing genetics exhibits may each uniquely help to foster genetic literacy and understanding.

Through this study, we aimed to understand the methodological choices behind building genetics literacy in museum exhibits using interviews with key museum personnel involved in creation and execution. This approach is one of many 
possible approaches to understand how exhibit design impacts the transmission of ideas in a museum setting and provides only one lens through which the final product should be viewed. Alternative approaches, such as reviewing visitor feedback, examining exhibit content, or visiting the exhibit in person would provide complementary data to develop a full picture of the visitor experience. We chose this particular approach to focus on the motivations behind the exhibits and to connect the choices made within the design process to emergent narrative from the exhibit itself.

\section{Fostering genetic literacy through interactivity}

We identified three categories of museums, where genetics was typified as either fun, relevant or the fuel for visitor discovery. These categories align closely with Hein's categories for learning in the museum [1995]. "Genetics is Fun" matches a Constructivist approach, "Genetics is Relevant" matches a Behaviorist approach and "Genetics is Discover" matches a Discovery Learning approach. The museums within the category "Genetics is Fun" use an approach to presenting genetics where visitor enjoyment is the primary goal, which is accomplished mostly through interactive exhibits. Interactivity, through physical touch or "gamification," has become a key component in museums exhibits. Research on visitor learning in museums suggests that interactivity promotes engagement, understanding, and recall of exhibits (for a review, see [Schneider, 2003] ). Engagement can also serve to scaffold new learning through metaphor, such as when in our interviews curators at the St. Louis Science Center described their replication and transcription exhibit, in which visitors cranked a handle to observe the process of "unzipping" the DNA and the nucleotides matching with their complementary base. Design elements of challenge and play have also been found to increase visit duration and visitor understanding of science [Perry, 2012]. Interactivity is further enhanced through staff or volunteers who guide audiences through demonstrations and presentations. Studies show that staffed exhibits have higher levels of attraction, holding power, and visitor engagement compared to unstaffed exhibits [Boisvert and Slez, 1995]. Genetics exhibits with staffed interactive components allow visitors to experience genetics in a way that brings them into the process of discovery. In addition, these facilitated experiences can provide a personalized experience that is responsive to visitor knowledge and interested level, answering specific questions and potentially addressing fears.

While increasing visitor enjoyment through fun and interactive exhibits is a high priority among exhibit designers [Carliner, 2003], others argue that the role of museums is to move beyond entertainment in order to be effective as teaching tools [Hein, 1995; Allen, 2004]. For genetics exhibits, there are a limited number of components that work well for interactivity (such as constructing a DNA model, completing Punnett squares, linking genes to behavior), and these interactives are often conceptually distant from one another. While many of the museums we spoke with came up with innovative approaches to making these disparate interactives personal (such as trait trees), it is unclear whether visitors were able to understand the connection between concepts and comprehend overarching goals. Though highly interactive exhibits can be successful at prolonged visitor retention, for genetics exhibits, they largely communicate what genetics does, as opposed to what genetics is. 
Moreover, museums can move beyond displaying information to fostering skills of scientific inquiry (such as asking questions and interpreting results) by inviting participants to engage in authentic genetics research, as in the Genetics of Taste Lab at the Denver Museum of Nature \& Science in the "Genetics is Discovery" category. Exhibits like these utilize the participation design principle, which asserts that visitor understanding is shaped by both physical experiences [Alt and Shaw, 1984], which occur during sample collection, and dialogic interactivity [Simon, 2010], which occurs during study-driven informal and meaningful interactions with scientific staff and volunteers. Evaluation data from the Denver case study shows that visitors both value and enjoy contributing to research, and, that by actively participating in science, they feel more capable of understanding complex scientific concepts [Burcham et al., 2020; Garneau et al., 2018]. This increased confidence in visitor learning indicates a positive effect on visitor self-efficacy beliefs - their judgments of their ability to deal with or succeed in a certain situation [Bandura, 1977] — regarding genetics.

This approach of visitor participation in museum research is contrasted by the "glassbox" style of genetics exhibits, also present within the "Genetics is Discovery" category, where visitors observe scientists conducting research inside a glass-walled laboratory. Studies show that these types of exhibits have a positive effect on visitors' perceptions of museums, challenging their assumptions that science is passive and that museums are home only to stale facts and dead things [Wylie, 2019]. Seeing scientists of diverse backgrounds in action can also work against commonly held assumptions about who is included in science [Miller, Nolla et al., 2018]. However, these types of exhibits also can leave visitors with an incomplete understanding of the research being conducted, because their interpretation is based only on what they observe, with no opportunities to address questions or misconceptions without an additional interpreter outside of the exhibit.

\section{Fostering genetic literacy through unifying themes in exhibits}

Emergent themes that have been found to support science learning outside of physical interactivity include the immediate apprehendability of the exhibit, conceptual coherence, and consideration of the diversity of learners [Allen, 2004]. Conceptual coherence is the communication of an abstract concept, theme, or model of science throughout many smaller exhibit pieces. Many museums within the "Genetics is Relevant" category communicated that they utilize a similar "big idea" method of exhibit design, where development is guided by "a one sentence statement that connects the visitor to the content and explains the relevance of the topic to them" [Pekarik, 2002]. Conceptual coherence is part of the constructivist teaching perspective that learners need exposure not only to physical experiences but also to concepts and models [Driver et al., 1994]. Conceptual coherence has been cited as a fundamental design tenet for creating an intrinsically motivating exhibit that is an effective teaching tool. The Oregon Museum of Science and Industry has used this concept to unite individual genetics topics like DNA basics, inheritance, genetic ancestry testing. and ethics through the "big idea" of Genghis Khan's genetic legacy. This approach allows visitors to follow an immediately apparent story and challenges them to answer specific related questions by relating complex genetics concepts to elements within the narrative. 
Another technique used by exhibit designers to emphasize unifying narratives is cognitive scaffolding [Wood, 2001], in which questions, prompts, and other structured interactions act as cognitive supports for learners during an extended investigation [Samarapungavan, Mantzicopoulos and Patrick, 2008], is another design principle used to make exhibit learning more effective by teaching inquiry skills. As supports (such as prompts and volunteer facilitators) gradually fade into the background during the activity, learners can continue autonomously [Collins, Brown and Newman, 2018; Vygotsky, 1980] . The Burke Museum of Natural History and Culture explicitly identifies this as a design tactic employed there, where leading questions within each exhibit section prompt discussion and docents to guide and facilitate activities. Exhibits that employ scaffolding not only aim to strengthen inquiry skills but also provide various levels of engagement for visitors, resonating with the design practices of skimmability and layering for modeling information in three-dimensional space [Carliner, 2003]. By presenting information at various levels of depth (gallery headings, theme labels, object labels), visitors are able to explore in as much detail as they like and always leave feeling that they have learned a complete topic [Carliner, 2003]. These practices mitigate both the cognitive overload and the physical museum fatigue experienced by visitors [Falk and Dierking, 1995; Falk, Koran et al., 2010]. Exhibits in the "Genetics is Relevant" category often supported science learning by using a compelling combination of expert and personal narratives within case studies to appeal to a diversity of learners. These narratives often not only discuss the "product" of genetic technology, but also the process of a particular technology's discovery. Researchers have noted that the narrative device is useful for stimulating personal reflection and discussion [Kelly, 2007; Pedretti, Navas-Iannini and Nazir, 2018]. This may be in part due to the sense of similarity, grounding scientific concepts in ways that are more accessible to visitors [Avraamidou and Osborne, 2009]. Because one of the goals of genetic literacy is to encourage decision-making following discussion and reflection, narratives are an invaluable tool of science communication. Further, case-based approaches are an ideal pedagogical model to highlight the real-world relevance of new theories [Boerwinkel, Yarden and Waarlo, 2017]. Additional frameworks that have been found to encourage evidence-based decision making and increase engagement with controversial socio-scientific exhibits are the principles of participatory design [Simon, 2010]. Participatory exhibits are both social and visitor-determined, allowing visitors to become co-creators of meaning through their interactions with the exhibit. Additional studies support that visitor gains are increased when exhibits are structured and collaborative rather than spontaneous and individualized [Gutwill and Allen, 2012].

\section{Fostering genetic literacy through framing}

Generally, genetics research is portrayed in a positive light in the media, an image which is supported through the use of quotations from researchers, references to credible sources, appeals to human interest, and the use of particular words, metaphors and analogies [Petersen, 2001]. Similar techniques are evident within exhibits across categories of museums, most notably with Science North's “Club Genome" as an extended, interactive analogy and with the case studies of scientists at the University of Nebraska State Museum. While the overall image of genetic research is positive, the framing of science in the media has often been that of popularization and disseminating factual content rather than presenting the 
technology within a societal context [Väliverronen, 2001]. With respect to genetics, media framing focuses more specifically on the novelty of cutting-edge genetic technology, framing the discoveries as "making breakthroughs" or an attempt at "playing God" [Hellsten and Nerlich, 2008]. Hansen [2006] argues that this type of binary narrative deters fruitful discussion surrounding the technology, as whatever cannot be classified as a natural phenomenon is by default potentially immoral, wrong, or dangerous, and is therefore antithetical to the goals of genetic literacy regarding critical thinking and independent decision-making [Hansen, 2006]. Further, framing of genetics and medical advancements primarily focuses on genes coding directly for individual traits rather than the complexity of the gene-environment-trait interplay, which is also at odds with the nuanced perspective genetic literacy offers [Gallop et al., 2017; Kampourakis, 2016; Pramling and Säljö, 2007; Stern and Kampourakis, 2017; Zolyan, 2020].

\section{Conclusion}

Improving genetic literacy is critical to increasing trust in science, and results in greater satisfaction with health decisions and decreases in the prevalence of naturalistic fallacies about race [Donovan, Semmens et al., 2019; Donovan, Weindling et al., 2020]. While museums have been successfully communicating about genetics for almost a hundred years, they must continually evolve to reflect emerging technologies and the national discourse. Museums have experienced several paradigm shifts, from "cabinets of curiosities," through "experiential fact-based science centers" (the popularization paradigm), to the now-popular critical exhibits, which are largely issues-based and encourage visitors to actively engage with and consider socio-scientific issues from many perspectives [Pedretti, 2002]. When applied to genetics, these frameworks promote decision-making, situate genetics technologies in social contexts, and encourage visitors to evaluate the certainty and uncertainty of genetic information and the (mis)representation of genetic knowledge in the media.

Our research sought to understand both common framing choices used to convey genetics content in museums and how these strategies each contribute to fostering genetic literacy, by analyzing the framing choices used to convey genetics content in museums. We identified three unique approaches used by exhibits, highlighting that genetics is fun, relevant, or based in discovery. While each of these frameworks can provide effective engagement, future genetics exhibits should consider design choices, messaging strategies, and learning goals, each with their own benefits and deficits, to develop exhibits that both inform and challenge in engaging ways to ultimately increase visitors' genetic literacy.

Acknowledgments This research was funded by the National Center for Science Education Graduate Student Science Outreach Fellowship in 2019 and 2020. 

McBride, C. M. (2016). 'Media Exposure and Genetic Literacy Skills to Evaluate Angelina Jolie's Decision for Prophylactic Mastectomy'. Public Health Genomics 19 (5), pp. 282-289. https : //doi .org/10.1159/000447944.

Allen, S. (2004). 'Designs for learning: Studying science museum exhibits that do more than entertain'. Science Education 88 (S1), S17-S33. https://doi.org/10.1002/sce. 20016.

Alt, M. B. and Shaw, K. M. (1984). 'Characteristics of ideal museum exhibits'. British Journal of Psychology 75 (1), pp. 25-36. https://doi.org/10.1111/j.2044-8295.1984.tb02786.x.

Andrew Elby, D. H. amd, Scherr, R. E. and Redish, E. F. (2004). 'Resources, framing, and transfer'. In: Transfer of Learning from a Modern Multidisciplinary Perspective. Ed. by J. P. Mestre. Greenwich, CT, U.S.A.: Information Age Publishing, pp. 89-119.

Antón, C., Camarero, C. and Garrido, M.-J. (2017). 'Exploring the experience value of museum visitors as a co-creation process'. Current Issues in Tourism 21 (12), pp. 1406-1425. https://doi.org/10.1080/13683500.2017.1373753.

Avraamidou, L. and Osborne, J. (2009). 'The Role of Narrative in Communicating Science'. International Journal of Science Education 31 (12), pp. 1683-1707. https://doi.org/10.1080/09500690802380695.

Bandura, A. (1977). 'Self-efficacy: toward a unifying theory of behavioral change'. Psychological Review 84 (2), pp. 191-215. https://doi.org/10.1037/0033-295x.84.2.191. PMID: 847061.

Bobkowski, P. S., Watson, J. C. and Aromona, O. O. (2020). 'A Little Bit of That from One of Your Grandparents: Interpreting Others' Direct-to-Consumer Genetic Ancestry Results'. Genealogy 4 (2), p. 54. https://doi.org/10.3390/genealogy4020054.

Boerwinkel, D. J., Yarden, A. and Waarlo, A. J. (2017). 'Reaching a Consensus on the Definition of Genetic Literacy that Is Required from a Twenty-First-Century Citizen'. Science \& Education 26 (10), pp. 1087-1114. https://doi.org/10.1007/s11191-017-9934-y.

Boisvert, D. L. and Slez, B. J. (1995). 'The relationship between exhibit characteristics and learning-associated behaviors in a science museum discovery space'. Science Education 79 (5), pp. 503-518. https://doi.org/10.1002/sce.3730790503.

Bonham, V. L., Citrin, T., Modell, S. M., Franklin, T. H., Bleicher, E. W. B. and Fleck, L. M. (2009). 'Community-Based Dialogue: Engaging Communities of Color in the United States' Genetics Policy Conversation'. Journal of Health Politics, Policy and Law 34 (3), pp. 325-359. https://doi.org/10.1215/03616878-2009-009.

Burcham, Z. M., Garneau, N. L., Comstock, S. S., Tucker, R. M., Knight, R. and Metcalf, J. L. (2020). 'Patterns of Oral Microbiota Diversity in Adults and Children: A Crowdsourced Population Study'. Scientific Reports 10 (1). https://doi.org/10.1038/s41598-020-59016-0.

Carliner, S. (2003). ‘Modeling Information for Three-dimensional Space: Lessons Learned from Museum Exhibit Design'. Technical Communication 50, pp. 554-570.

Chen, L.-S. and Goodson, P. (2007). 'Public Health Genomics knowledge and attitudes: A survey of public health educators in the United States'. Genetics in Medicine 9 (8), pp. 496-503. https://doi.org/10.1097/gim.0b013e31812e95b5. 
Ciske, D. J., Haavisto, A., Laxova, A., Rock, L. Z. M. and Farrell, P. M. (2001). 'Genetic Counseling and Neonatal Screening for Cystic Fibrosis: An Assessment of the Communication Process'. Pediatrics 107 (4), pp. 699-705. https://doi.org/10.1542/peds.107.4.699.

Collins, A., Brown, J. S. and Newman, S. E. (2018). 'Cognitive Apprenticeship: Teaching the Crafts of Reading, Writing, and Mathematics'. In: Knowing, Learning, and Instruction. Routledge, pp. 453-494. https://doi.org/10.4324/9781315044408-14.

Diamond, J. (1986). 'The behavior of family groups in science museums'. Curator: The Museum Journal 29 (2), pp. 139-154. https://doi.org/10.1111/j.2151-6952.1986.tb01434.x.

Donovan, B. M. (2016). 'Framing the Genetics Curriculum for Social Justice: An Experimental Exploration of How the Biology Curriculum Influences Beliefs About Racial Difference'. Science Education 100 (3), pp. 586-616. https://doi.org/10.1002/sce.21221.

Donovan, B. M., Semmens, R., Keck, P., Brimhall, E., Busch, K. C., Weindling, M., Duncan, A., Stuhlsatz, M., Bracey, Z. B., Bloom, M., Kowalski, S. and Salazar, B. (2019). 'Toward a more humane genetics education: Learning about the social and quantitative complexities of human genetic variation research could reduce racial bias in adolescent and adult populations'. Science Education 103 (3), pp. 529-560. https://doi.org/10.1002/sce.21506.

Donovan, B. M., Weindling, M., Salazar, B., Duncan, A., Stuhlsatz, M. and Keck, P. (2020). 'Genomics literacy matters: Supporting the development of genomics literacy through genetics education could reduce the prevalence of genetic essentialism'. Journal of Research in Science Teaching 58 (4), pp. 520-550. https://doi.org/10.1002/tea.21670.

Driver, R., Asoko, H., Leach, J., Scott, P. and Mortimer, E. (1994). 'Constructing Scientific Knowledge in the Classroom'. Educational Researcher 23 (7), pp. 5-12. https://doi.org/10.3102/0013189x023007005.

Duensing, S. (2006). 'Culture Matters: Informal Science Centers and Cultural Contexts'. Counterpoints 249, pp. 183-202.

Dunbar, K. and Klahr, D. (2013). 'Developmental Differences in Scientific Discovery Processes'. In: Complex Information Processing. Ed. by D. Klahr and K. Kotovsky. Psychology Press. https://doi.org/10.4324/9780203761618.

Ellenbogen, K. M. (2003). 'Museums in Family Life: An Ethnographic Case Study'. In: Learning Conversations in Museums. Ed. by G. Leinhardt, K. Crowley and K. Knutson. 1st ed. Routledge. https://doi .org/10.4324/9781410606624.

Evans, E. M., Spiegel, A., Gram, W., Frazier, B. N., Cover, S., Tare, M. and Diamond, J. (2010). 'A Conceptual Guide to Natural History Museum Visitors' Understanding of Evolution'. Educational Psychology Papers and Publications. URL: http://digitalcommons . unl . edu/edpsychpapers/195.

Falk, J. H. and Dierking, L. D., eds. (1995). Public institutions for personal learning: establishing a research agenda. Washington, D.C., U.S.A.: American Alliance Of Museums.

Falk, J. H., Dierking, L. D., Swanger, L. P., Staus, N., Back, M., Barriault, C., Catalao, C., Chambers, C., Chew, L.-L., Dahl, S. A., Falla, S., Gorecki, B., Lau, T.-C., Lloyd, A., Martin, J., Santer, J., Singer, S., Solli, A., Trepanier, G., Tyystjärvi, K. and Verheyden, P. (2016). 'Correlating science center use with adult science literacy: an international, cross-institutional study'. Science Education 100 (5), pp. 849-876. https://doi .org/10.1002/sce.21225. 
Falk, J. H., Koran, J. J., Dierking, L. D. and Dreblow, L. (2010). ‘Predicting Visitor Behavior'. Curator: The Museum Journal 28 (4), pp. 249-258. https://doi.org/10.1111/j.2151-6952.1985.tb01753.x.

Falk, J. H. and Storksdieck, M. (2005). 'Learning science from museums'. História, Ciências, Saúde-Manguinhos 12 (Suppl.), pp. 117-143.

https://doi.org/10.1590/s0104-59702005000400007.

Gallop, L., Chapman, R., Selita, F. and Kovas, Y. (2017). 'Effects Of Education And Media Framing On Genetic Knowledge And Attitudes'. In: The European Proceedings of Social and Behavioural Sciences. Cognitive-Crcs. https://doi.org/10.15405/epsbs.2017.12.13.

Garneau, N. L., Nuessle, T. M., Mendelsberg, B. J., Shepard, S. and Tucker, R. M. (2018). 'Sweet liker status in children and adults: Consequences for beverage intake in adults'. Food Quality and Preference 65, pp. 175-180. https://doi.org/10.1016/j.foodqual.2017.10.005.

Gutwill, J. P. and Allen, S. (2012). 'Deepening Students' Scientific Inquiry Skills During a Science Museum Field Trip'. Journal of the Learning Sciences 21 (1), pp. 130-181. https://doi.org/10.1080/10508406.2011.555938.

Hales, K. G. (2020). 'Signaling Inclusivity in Undergraduate Biology Courses through Deliberate Framing of Genetics Topics Relevant to Gender Identity, Disability, and Race'. CBE-Life Sciences Education 19 (2). Ed. by R. Price, es2. https://doi.org/10.1187/cbe.19-08-0156.

Hansen, A. (2006). 'Tampering with nature: 'nature' and the 'natural' in media coverage of genetics and biotechnology'. Media, Culture $\mathcal{E}$ Society 28 (6), pp. 811-834. https://doi.org/10.1177/0163443706067026.

Hein, G. E. (1995). 'The Constructivist Museum'. Journal of education in Museums 16 (1), pp. 21-23.

Hellsten, I. R. and Nerlich, B. (2008). 'Genetics and Genomics The Politics and Ethics of Metaphorical Framing'. In: Handbook of Public Communication of Science and Technology. Ed. by M. Bucchi and B. Trench. London, U.K. and New York, U.S.A.: Routledge, pp. 93-109.

Henning, M. (2006). 'New Media'. In: A companion to museum studies. Ed. by S. Macdonald. Oxford, U.K.: Blackwell Publishing Ltd, pp. 302-318. https://doi.org/10.1002/9780470996836.ch18.

Hinojosa, L. (2020). 'Identity Development, Participation, and Equity in Museum Community Science Programs'. Doctoral Dissertation. U.S.A.: University of Colorado at Boulder.

Hinojosa, L., Swanson, R. D. and Polman, J. L. (2018). Community Science Identity: Becoming Community Scientists in a Museum-based Genetics of Taste Program. URL: https://repository.isls.org//handle/1/700.

Holmes, J. A. (2011). 'Informal learning: Student achievement and motivation in science through museum-based learning'. Learning Environments Research 14 (3), pp. 263-277. https://doi.org/10.1007/s10984-011-9094-y.

Jamieson, A. and Radick, G. (2017). 'Genetic Determinism in the Genetics Curriculum'. Science E Education 26 (10), pp. 1261-1290. https://doi.org/10.1007/s11191-017-9900-8.

Kampourakis, K. (2016). 'The Bad Use of Metaphors and the Use of Bad Metaphors'. Science E Education 25 (9-10), pp. 947-949. https://doi.org/10.1007/s11191-016-9870-2.

Kelly, L. J. (2007). 'The Interrelationships Between Adult Museum Visitors' Learning Identities and Their Museum Experience'. Doctoral Dissertation. Australia: University of Technology, Sydney. 
Kemp, C. (2015). 'Museums: The endangered dead'. Nature 518 (7539), pp. 292-294. https://doi.org/10.1038/518292a.

Kirk, J. (2017). Framing Climate Change : The climate scepticist framing of climate change by the National Museum of Natural History, Washington, DC. Student Paper. URL: http://lup.lub.lu.se/student-papers/record/8906969.

Lofland, J. and Lofland, L. H. (1995). Analyzing social settings: a guide to qualitative observation and analysis. 3rd ed. Belmont, CA, U.S.A.: Wadsworth.

MacFadden, B. J. (2008). 'Evolution, museums and society'. Trends in Ecology $\mathcal{E}$ Evolution 23 (11), pp. 589-591. https://doi.org/10.1016/j.tree.2008.06.006.

Miller, D. I., Nolla, K. M., Eagly, A. H. and Uttal, D. H. (2018). 'The development of children's gender-science stereotypes: a meta-analysis of 5 decades of U.S. draw-a-scientist studies'. Child Development 89 (6), pp. 1943-1955. https://doi.org/10.1111/cdev.13039.

Miller, J. D. and Barrington, T. M. (1981a). 'The Acquisition and Retention of Scientific Information'. Journal of Communication 31 (2), pp. 178-189. https://doi.org/10.1111/j.1460-2466.1981.tb01240.x.

- (1981b). 'The Acquisition and Retention of Scientific Information'. Journal of Communication 312, pp. 178-189. https://doi.org/10.1111/j.1460-2466.1981.tb01240.x.

National Research Council (2000). How People Learn. Brain, Mind, Experience, and School: Expanded Edition. National Academies Press. https://doi.org/10.17226/9853.

Nisbet, M. C. and Mooney, C. (2007). 'Framing Science'. Science 316 (5821), pp. 56-56. https://doi.org/10.1126/science.1142030.

Nuessle, T. M., McNamara, P. A. and Garneau, N. L. (2020). 'Using Museum Guests as Crowdsourced Participants in Human Subject Research'. Curator: The Museum Journal 63 (3), pp. 407-429. https: //doi.org/10.1111/cura.12371.

Pearson, Y. E. and Liu-Thompkins, Y. (2012). 'Consuming Direct-to-Consumer Genetic Tests: The Role of Genetic Literacy and Knowledge Calibration'. Journal of Public Policy \& Marketing 31 (1), pp. 42-57. https://doi.org/10.1509/jppm.10.066.

Pedretti, E. (2002). 'T. Kuhn meets T. Rex: critical conversations and new directions in science centres and science museums'. Studies in Science Education 37 (1), pp. 1-41. https://doi.org/10.1080/03057260208560176.

Pedretti, E., Navas-Iannini, A. M. and Nazir, J. (2018). 'Exploring controversy in science museums: non-visitors and the body worlds exhibits'. Canadian Journal of Science, Mathematics and Technology Education 18 (2), pp. 98-113. https://doi.org/10.1007/s42330-018-0014-3.

Pekarik, A. J. (2002). Developing interactive exhibitions at the Smithsonian. Washington, D.C., U.S.A.: Smithsonian Institution, Office of Policy and Analysis. URL: http://hdl . handle.net/10088/17241.

Perry, D. L. (2012). What Makes Learning Fun? Principles for the Design of Intrinsically Motivation Museum Exhibits. Lanham, MD. U.S.A.: AltaMira Press.

Petersen, A. (2001). 'Biofantasies: genetics and medicine in the print news media'. Social Science $\mathcal{E}$ Medicine 52 (8), pp. 1255-1268. https://doi.org/10.1016/s0277-9536(00)00229-x.

Pramling, N. and Säljö, R. (2007). 'Scientific Knowledge, Popularisation, and the Use of Metaphors: Modern genetics in popular science magazines'. Scandinavian Journal of Educational Research 51 (3), pp. 275-295. https://doi.org/10.1080/00313830701356133. 
Ritchie, J. R. B. and Hudson, S. (2009). 'Understanding and meeting the challenges of consumer/tourist experience research'. International Journal of Tourism Research 11 (2), pp. 111-126. https://doi.org/10.1002/jtr.721.

Rock, J., McGuire, M. and Rogers, A. (2018). 'Multidisciplinary Perspectives on Co-creation'. Science Communication 40 (4), pp. 541-552. https://doi.org/10.1177/1075547018781496.

Roth, W. D., Yaylacı, S., Jaffe, K. and Richardson, L. (2020). ‘Do genetic ancestry tests increase racial essentialism? Findings from a randomized controlled trial'. PLOS ONE 15 (1). Ed. by M. H. Withers, e0227399. https://doi.org/10.1371/journal . pone.0227399.

Ryan, G. W. and Bernard, H. R. (2003). 'Techniques to Identify Themes'. Field Methods 15 (1), pp. 85-109. https://doi.org/10.1177/1525822x02239569.

Sabatello, M., Chen, Y., Sanderson, S. C., Chung, W. K. and Appelbaum, P. S. (2019). 'Increasing genomic literacy among adolescents'. Genetics in Medicine 21 (4), pp. 994-1000. https://doi.org/10.1038/s41436-018-0275-2.

Samarapungavan, A., Mantzicopoulos, P. and Patrick, H. (2008). ‘Learning science through inquiry in kindergarten'. Science Education 92 (5), pp. 868-908. https://doi.org/10.1002/sce. 20275.

Sauven, P. (2004). 'Guidelines for the management of women at increased familial risk of breast cancer'. European Journal of Cancer 40 (5), pp. 653-665. https://doi.org/10.1016/j.ejca.2003.10.028.

Scheuner, M. T., Sieverding, P. and Shekelle, P. G. (2008). 'Delivery of Genomic Medicine for Common Chronic Adult Diseases'. JAMA 299 (11), p. 1320. https://doi.org/10.1001/jama.299.11.1320.

Schmitt-Scheersoi, A., Vogt, H. and Naumann, C. (2002). The development of situation interests in an informal learning environment - a visitor evaluation study in an educational exhibition on individuality.

Schneider, B. (2003). Measuring Results: Gaining Insight on Behavior Change Strategies and Evaluation Methods from Environmental Education, Museum, Health, and Social Marketing Programs. San Francisco, CA, U.S.A.: Coevolution Institute.

Simon, N. (2010). The participatory museum. Santa Cruz, CA, U.S.A.: Museum 2.0.

Smerecnik, C. M., Mesters, I., de Vries, N. K. and de Vries, H. (2008). 'Educating the general public about multifactorial genetic disease: applying a theory-based framework to understand current public knowledge'. Genetics in Medicine 10 (4), pp. 251-258. https://doi.org/10.1097/gim.0b013e31816b4ffd.

Stephens, S. (2012). ‘From Tree to Map: Using Cognitive Learning Theory to Suggest Alternative Ways to Visualize Macroevolution'. Evolution: Education and Outreach 5 (4), pp. 603-618. https://doi .org/10.1007/s12052-012-0457-3.

Stern, F. and Kampourakis, K. (2017). 'Teaching for genetics literacy in the post-genomic era'. Studies in Science Education 53 (2), pp. 193-225. https://doi.org/10.1080/03057267.2017.1392731.

Taffe, S. and Kelly, M. (2020). 'Exchanging Expertise across Cultures and Time: Participatory Design Approaches for Creating Community Museums'. The Design Journal 23 (5), pp. 715-734. https://doi.org/10.1080/14606925.2020.1807717.

Tison Povis, K. (2017). 'Designing for Family Learning in Museums: How Framing, Joint Attention, Conversation, and Togetherness are at Play'. Doctoral Dissertation. Pittsburgh, U.S.A.: University of Pittsburgh.

University of Michigan School of Public Health (2007). Genomics, Community and Equity: A Continuing Dialogue Final Report. 
Väliverronen, E. (2001). 'Popularisers, Interpreters, Advocates, Managers and Critics'. Nordicom Review 22 (2), pp. 39-47. https://doi.org/10.1515/nor-2017-0353.

Vygotsky, L. S. (1980). Mind in society: the development of higher psychological processes. Cambridge, MA, U.S.A.: Harvard University Press.

Wandeler, P., Hoeck, P. E. A. and Keller, L. F. (2007). 'Back to the future: museum specimens in population genetics'. Trends in Ecology \& Evolution 22 (12), pp. 634-642. https://doi.org/10.1016/j.tree.2007.08.017.

Wilde, M. and Urhahne, D. (2008). 'Museum learning: a study of motivation and learning achievement'. Journal of Biological Education 42 (2), pp. 78-83. https://doi.org/10.1080/00219266.2008.9656115.

Wood, D. (2001). 'Scaffolding, contingent tutoring, and computer-supported learning'. International Journal of Artificial Intelligence in Education 12, pp. 280-292.

Wylie, C. D. (2019). 'Glass-boxing Science: Laboratory Work on Display in Museums'. Science, Technology, E Human Values 45 (4), pp. 618-635. https://doi.org/10.1177/0162243919871101.

Zimmerman, H. T., Reeve, S. and Bell, P. (2009). 'Family sense-making practices in science center conversations'. Science Education 94 (3), pp. 478-505. https://doi.org/10.1002/sce. 20374.

Zolyan, S. T. (2020). 'Does a Ribosome Really Read? On the Cognitive Roots and Heuristic Value of Linguistic Metaphors in Molecular Genetics. Part 1'. Russian Journal of Philosophical Sciences 63 (1), pp. 101-115. https://doi .org/10.30727/0235-1188-2020-63-1-101-115.

Authors

Abigail A. Howell is a PhD student in molecular and cellular biology at Arizona State University. E-mail: aahowel3@asu.edu.

Keighley N. Reisenauer is a lecturer in Biology at Baylor University. E-mail: keighleyreisenauer@gmail.com.

Michelle M. Valkanas is an assistant professor in Biology at California University of Pennsylvania. E-mail: valkanas@calu.edu.

Katherine E. Carter is the Director of Science Communication at Phillip and Patricia Frost Museum of Science. E-mail: kcarter@frostscience.org.

\section{How to cite}

Howell, A. A., Reisenauer, K. N., Valkanas, M. M. and Carter, K. E. (2022). 'Beyond the Base-ics: approaches to driving connection through genetics in museums'. JCOM 21 (01), A02. https:/ / doi.org/10.22323/2.21010202. 